\title{
Motivasi Mahasiswa Tingkat Akhir dengan Kecemasan Mendapatkan Pekerjaan
}

\author{
Yuliastri Ambar Pambudhi ${ }^{1}$, Waode Suarni² \& Ali Rudin ${ }^{3}$ \\ Jurusan Psikologi \\ Fakultas Keguruan dan Ilmu Pendidikan, Universitas Halu Oleo \\ yul_psy@yahoo.com¹, waodesuarni@yahoo.com², alirudin013@gmail.com³
}

\begin{abstract}
Abstrak : Kecemasan mendapatkan pekerjaan merupakan respon terhadap situasi tertentu yang ditandai dengan perasaan yang tidak menyenangkan karena banyaknya persaingan Jurusan untuk mendapatkan pekerjaan. Hal ini dapat memberikan dampak kurangnya motivasi menyelesaikan studi. Penelitian ini bertujuan untuk melihat hubungan antara motivasi menyelesaikan studi dengan kecemasan mendapatkan pekerjaan pada mahasiswa tingkat akhir Jurusan Antropologi Universitas Halu Oleo. Subjek penelitian ini dilaksanakan pada mahasiswa tingkat akhir di jurusan Antropologi yang berjumlah 60 orang dari angkatan 2014-2016 jenis kelamin laki-laki dan perempuan umur 21-26 tahun. Sumber data penelitian ini adalah mahasiswa diukur dengan menggunakan skala motivasi dan kecemasan. Teknik pengambilan sampel menggunakan Stratified Random Sampling. Data hasil penelitian dianalisis dengan menggunakan korelasi Product Moment Pearson. Berdasarkan data penelitian maka disimpulkan bahwa hipotesis dalam penelitian ini tidak diterima. Dari hasil analisis data yang ditemukan bahwa nilai signifikansi sebesar 0,144 yang artinya tidak ada hubungan antara motivasi menyelesaikan studi dengan kecemasan mendapatkan pekerjaan pada mahasiswa Jurusan Antropologi Universitas Halu Oleo. Analisis deskriptif juga menjelaskan bahwa motivasi menyelesaikan studi dan juga kecemasan mendapatkan pekerjaan paling banyak dialami kategori sedang.
\end{abstract}

Kata kunci : motivasi ; kecemasan ; mahasiswa

\begin{abstract}
Anxiety to getting a job is a response to certain situations characterized by unpleasant feelings because of the many competition for the department to get a job. This can result a lack of motivation to complete the study. This study aimed to see the relationship between motivation to complete study with anxiety about getting a job in the final year students of the Anthropology Department, Halu Oleo University. The subjects of this study were carried out at the final year students of the Anthropology department, totaling 60 people from the 2014-2016 class, male and female aged 21-26 years. The data source of this research is collage students that are measured by using a scale of motivation and anxiety. The sampling technique used stratified random sampling. The research data were analyzed using Pearson Product Moment Correlation. Based on the research data, it can be concluded that the hypothesis in this study was not accepted. From the results of data analysis, it was found that the significance value was 0.144 , which means there was no relationship between motivation to complete the study and anxiety about getting a job among students of the Department of Anthropology, University of Halu Oleo. Descriptive analysis also explains that the motivation to complete the study and also anxiety about getting a job is mostly experienced in the moderate category.
\end{abstract}

Keywords : motivation ; anxiety ; collage student 


\section{Pendahuluan}

Sumber daya manusia menjadi salah satu hal penting bagi negara berkembang seperti Indonesia dalam Peningkatan mutu sumber daya manusia tidak terlepas dari pendidikan yang secara umum diidentikkan dengan pendidikan formal. Pendidikan tinggi atau yang biasa dikenal dengan perguruan tinggi adalah salah satu tempat proses pembelajaran dengan tujuan untuk memperdalam ilmu sebagai bekal dalam menghadapi dunia kerja kedepannya. Individu yang belajar di perguruan tinggi selanjutnya dikenal sebagai mahasiswa.

Setiap mahasiswa yang aktif dalam bangku perkuliahan menginginkan gelar sarjana sebagai tujuan akhir, namun untuk mendapatkan hal tersebut seorang mahasiswa harus menempuh perkuliahan dengan menyelesaikan skripsi sebagai salah satu syarat kelulusan. Mahasiswa yang telah memasuki tahap akhir semester perkuliahan, disebut mahasiswa tingkat akhir.

Mahasiswa tingkat akhir adalah mahasiswa yang sedang dalam proses mengerjakan skripsi sebagai syarat kelulusan sehingga wajib dikerjakan bagi mahasiswa yang ingin menyelesaikan studi dan mendapatkan gelar sarjana. Mahasiswa tingkat akhir dituntut untuk membuat sebuah karya ilmiah dari hasil penelitian yang dilakukan dan diharapkan dapat bermanfaat bagi masyarakat secara umum.

Mahasiswa masuk perguruan tinggi
dengan tujuan untuk mendapatkan
pekerjaan yang sesuai dengan bidang yang
diinginkan. Mahasiswa berharap dengan
bekal yang telah didapatkan saat kuliah,
setelah lulus mendapatkan pekerjaan
dengan mudah sesuai dengan bidangnya.
Kini pada kenyataannya, mendapatkan
pekerjaan bukan suatu hal yang mudah,
apalagi jika kriteria pekerjaan yang akan
dipilih adalah pekerjaan yang dicita-
citakan baik bagi individu maupun

keluarga. Mahasiswa berada pada perkembangan masa dewasa awal, salah satu tahap perkembangan pada masa dewasa awal adalah telah merencanakan karir, namun sebagai mahasiswa menyelesaikan studi merupakan tahap yang harus dilewati. (Yuniarto, 2017). Sama halnya yang diutarakan oleh Nugroho \& Karyono (2015) paling diakui sebagai tanda yang paling memasuki masa dewasa adalah ketika seseorang mendapatkan pekerjaan yang sesuai dengan apa yang mereka impikan.

Menurut Bandura (dalam Nevid, Rathus, \& Greene, 2005) bila individu percaya bahwa dirinya tidak mempunyai kemampuan untuk menghadapi tantangan dalam hidupnya, maka individu tersebut akan semakin cemas bila dihadapkan pada suatu tantangan, seperti tantangan dalam menghadapi dunia kerja yang akan dihadapkan oleh mahasiswa tingkat akhir setelah lulus dari perguruan tinggi.

Mendapatkan pekerjaan selalu dihadapkan pada persaingan, dan tidak jarang pula dunia kerja menghendaki calon tenaga kerja yang memiliki keterampilan yang diharapkan misalnya, memiliki pengalaman kerja, menguasai bahasa asing, menguasai teknologi, serta kecakapan-kecakapan lain, sehingga halhal tersebut dapat menimbulkan kecemasan pada mahasiswa. Menurut Tohill \& Holyoak (dalam Das, Halder, \& Mishra, 2014) kecemasan adalah sesuatu yang hampir menimpa setiap orang pada waktu tertentu dalam kehidupannya seperti menimpa kecemasan dalam bidang akademis. Sedangkan menurut Huberty (dalam Hooda \& Saini, 2017) kecemasan juga merupakan reaksi normal terhadap situasi yang sangat menekan kehidupan seseorang dalam hal dunia kerja.

Greenberger \& Padesky (dalam Hanim \& Ahlas, 2020) menyatakan bahwa kecemasan sebagai suatu kegugupan atau rasa takut sementara ketika dihadapkan pada pengalaman yang sulit dalam 
kehidupan.

Mendapatkan pekerjaan menjadi keinginan pertama bagi setiap individu yang sebagian besar lulusan dari perguruan tinggi, namun untuk mendapatkan pekerjaan tersebut salah satu syarat yang sering diajukan perusahaan merupakan strata pendidikan dan juga gelar. Jurusan menjadi salah satu faktor yang penting bagi individu untuk masuk dalam suatu instansi, sebagai penentu peluang individu dalam mendapatkan pekerjaan. Menurut Susantoputri, Kristiana, \& Gunawan (2014) dalam proses mempersiapkan diri dalam dunia kerja, seorang mahasiswa perlu perlu mempunyai keyakinan tentang dirinya, yakin dengan ciri-ciri kepribadian yang menonjol, yakin akan potensi intelektualnya dari mahasiswa lain, serta dapat menerima perbedaan tersebut. Mahasiswa harus menentukan dengan tepat bidang karir atau jenis pekerjaan yang sesuai dengan mereka jauh sebelum mereka dinyatakan lulus oleh institusi.

Dikutip dari detik.com salah satu Jurusan yang kurang dibutuhkan oleh instansi atau perusahaan di dunia salah satunya adalah Jurusan Antropologi yang memiliki presentasi Angka pengangguran di dunia, presentase penganggurannya mencapai $10,2 \%$. Data ini menunjukkan bahwa Jurusan Antropologi memiliki presentase pengangguran yang tinggi, sehingga kecenderungan untuk mengalami kecemasan dalam dunia kerja. Hal ini menunjukkan bahwa tidak semua disiplin ilmu memiliki peluang besar dalam mencari pekerjaan di era modern ini. Sama halnya berdasarkan data menurut Zul \& Ang (Nadziri, 2018) bahwa terdapat 10 jurusan yang tidak banyak dicari oleh perusahaan baik perusahaan dalam Negeri maupun Luar Negeri, diantaranya adalah Bahasa dan Sastra dengan angka pengangguran di dunia pada Jurusan ini mencapai 9.2\%, Antropologi dan Sejarah, persentasi pengangguran sebesar $10.2 \%$, Seni Komersial dan Desain Grafis mencapai 11.8\%, Kebugaran Fisik, Taman Bermain dan Musik dengan persentase pengangguran sebesar $8.3 \%$.

Berdasarkan hasil dari penyebaran angket untuk mengidentifikasi kecemasan pada mahasiswa Jurusan Antropologi dari angkatan 2014, 2015 dan 2016 ditemukan bahwa dari 40 mahasiswa, 30 mahasiswa teridentifikasi mengalami kecemasan dan 10 mahasiswa lainnya tidak teridentifikasi. Hal ini menunjukkan bahwa mahasiswa Jurusan Antropologi Universitas Halu Oleo sebagian teridentifikasi mengalami kecemasan dalam menghadapi dunia kerja.

Mendalami hasil angket yang telah disebarkan, peneliti melakukan wawancara kepada 3 mahasiswa pada tanggal 13 September 2019, subjek ke 1 mengatakan beberapa mahasiswa mengalami kekhawatirannya akan kemampuan dalam bekerja, khawatir tidak mendapatkan pekerjaan, mengalami kegelisahan serta ketakutan bila memikirkan dunia kerja, cemas karena kurang pengalaman kerja yang membuat mereka terganggu dengan hal tersebut dan sengaja memperlambat dalam menyelesaikan skripsi, karena mereka tidak memiliki motivasi untuk cepat selesai dalam menyelesaikan studi, hal ini sesuai dengan pendapat Lestari (2012), motivasi sangatlah dibutuhkan oleh para mahasiswa dalam proses menyelesaikan studi. McClelland (1987) dimana motivasi adalah proses yang memberikan semangat setiap orang, akan tetapi semangat tersebut bisa menurun karena individu itu sendiri. Motivasi yang tinggi pada individu akan memberikan dampak atau dukungan sehingga dapat memaksimalkan pencapaian tujuan yang akan ditetapkan. Begitupun sebaliknya dengan individu yang memiliki motivasi yang rendah secara langsung juga akan menghambat proses pencapaian tujuannya.

Kecemasan akan muncul ketika dihadapkan pada sesuatu yang mengancam di luar kemampuannya. Salah satu faktor yang mempengaruhi tinggi rendahnya kecemasan menghadapi dunia kerja adalah faktor kognitif (Rosliani \& Ariati, 2016). Seperti sulit tidur, sulit konsentrasi, dan tidak fokus pada saat situasi tertentu, 
situasi tersebut ketika mereka sendiri memikirkan dunia kerja karena merasa khawatir nantinya saat memperoleh gelar sarjana akan kesulitan untuk memperoleh pekerjaan yang sesuai dengan bidangnya, dan merasa gelisah tidak yakin dengan kemampuannya.

Menurut Durand \& Barlow (2006) kecemasan menghadapi dunia kerja yang dialami oleh mahasiswa adalah keadaan suasana hati dimana individu merasa cemas terhadap kegagalan yang akan dihadapi dimasa mendatang, serta sesuatu yang buruk akan terjadi ditandai oleh efek negatif dan gejala-gejala ketegangan jasmaniah, adanya kekhawatiran dan merasa takut tentang sesuatu yang terjadi dimasa depan, karena banyaknya lulusan sehingga terjadi persaingan untuk mendapatkan pekerjaan sesuai dengan bidangnya, kemudian mereka juga beranggapan bahwa mendapatkan pekerjaan sangatlah tidak mudah, kecuali mereka harus mempunyai keahlian dalam bidang yang sesuai dengan jurusannya. Sependapat dengan Agusta (2015) bahwa calon sarjana diharapkan memiliki kemampuan sesuai dengan bidangnya, mampu mengembangkan pengetahuan, serta memiliki wawasan dan pengetahuan yang luas dengan harapan mahasiswa dapat bersaing dengan sarjana lulusan lain dalam dunia kerja.

Hasil wawancara di atas menunjukkan bahwa mahasiswa Jurusan Antropologi mengalami gelaja kecemasan dalam menghadapi dunia kerja. Kondisi tersebut sesuai dengan pendapat Ramaiah (2003) bahwa kecemasan ditandai dengan adanya beberapa gejala yang muncul seperti kegelisahan, ketakutan terhadap sesuatu yang terjadi dimasa depan, merasa tidak tentram, sulit untuk berkonsentrasi, dan merasa tidak mampu untuk mengatasi masalah. Kecemasan biasanya dapat menimbulkan dua akibat yaitu kepanikan yang sangat dalam menyesuaikan diri pada situasi, dan gagal mengetahui terlebih dahulu bahaya dan mengambil tindakan pencegahan yang cukup.

Mahasiswa memerlukan strategi yang tepat untuk menghadapi kemungkinan yang akan terjadi di masa depan berupa motivasi internal yang berakibat pada timbulnya keinginan untuk menentukan tujuan-tujuan yang ingin dicapai serta melakukan evaluasi dan modifikasi terhadap perilaku sendiri (Azhari \& Mirza, 2016).

Berdasarkan latar belakang di atas peneliti tertarik untuk melakukan penelitian yang berjudul "Hubungan Antara Motivasi Menyelesaikan Studi dengan Kecemasan Mendapatkan Pekerjaan Pada Mahasiwa Tingkat Akhir Jurusan Antropologi Universitas Halu Oleo."

\section{Metode Penelitian}

Penelitian ini merupakan penelitian kuantitatif dengan menggunakan desain penelitian korelasional. Identifikasi variabel dalam penelitian ini adalah variabel terikat (Y) kecemasan mendapatkan pekerjaan dan variabel bebas (X) motivasi menyelesaikan studi. Populasi dalam penelitian ini ialah mahasiswa Jurusan Antropologi Universitas Halu Oleo dengan total populasi sebanyak 151 mahasiswa yang terdiri dari angkatan 2014-2016. Teknik penarikan sampel dalam penelitian ini menggunakan teknik penarikan sampel acak terlapis (Stratified Random Sampling) sehingga ditemukan sampel sebanyak 60 mahasiswa. Metode pengumpulan data menggunakan Academic Motivation Scale (AMS) untuk mengukur motivasi menyelesaikan studi skala dari Natalya \& Purwanto (2018), yang dimodifikasi oleh peneliti dan juga skala kecemasan mendapatkan pekerjaan teori dari Nevid, Rathus, \& Greene (2005) dibuat oleh peneliti.

Hasil validitas skala kecemasan mendapatkan pekerjaan menunjukkan 
bahwa dari 80 item yang telah dianalisis, 59 item dinyatakan valid sedangkan 21 item lainnya dikatakan gugur, karena tidak memenuhi standar koefisien korelasi yang telah ditetapkan yakni $\geq 0,25$. Sedangkan hasil uji coba skala Academic Motivation Scale (AMS) untuk mengukur motivasi menyelesaikan studi menunjukkan bahwa dari 40 item yang telah dianalisis, 37 item dinyatakan valid sedangkan 3 item lainya dinyatakan gugur, karena tidak memenuhi standar koefisien korelasi yang telah ditetapkan yakni $\geq 0,25$.

Data penelitian ini memiliki nilai reliabilitas untuk variabel kecemasan mendapatkan pekerjaan dengan nilai Cronbach's Alpha 0,968 dan variabel motivasi menyelesaikan studi dengan nilai Cronbach's Alpha 0,748.

Data penelitian dianalisis dengan menggunakan teknik analisis data deskriptif dan juga teknik analisis data inferensial. Pada teknik analisis data inferensial peneliti menggunakan teknik analisis data korelasi Product Moment Pearson untuk menguji hipotesis dalam penelitian.

\section{Hasil Penelitian dan Pembahasan}

Uji normalitas dilakukan untuk mengetahui apakah data terdistribusi normal atau tidak. Data penelitian terdistribusi normal dapat dikatakan mewakili keadaan populasi yang sebenarnya, yang artinya hasil penelitian dapat digeneralisasi pada populasi tersebut. Uji normalitas penelitian ini menggunakan teknik analisis KolmogrovSmirnov, yang dimana taraf signifikansi ( $\rho)$ lebih besar dari $0,05(\rho \geq 0,05)$ maka data terdistribusi normal. Adapun hasil uji normalitas dapat dilihat pada tabel berikut ini.
Tabel 1. Uji Normalitas

\begin{tabular}{ccl}
\hline Variabel & Signifikansi & Keterangan \\
\hline $\begin{array}{c}\text { Kecemasan } \\
\text { Mendapatkan Pekerjaan } \\
\text { X }\end{array}$ & 0,200 & Normal \\
$\begin{array}{c}\text { Motivasi } \\
\text { Menyelesaikan Studi }\end{array}$ & 0,072 & Normal \\
\hline
\end{tabular}

Uji linearitas bertujuan untuk melihat hubungan antar variabel yang akan diuji memiliki hubungan yang lurus (linear) atau tidak secara signifikan. Uji linearitas menunjukkan nilai Test for Linearity sebesar 0,760 dengan bantuan SPSS 23.0 for Windows. Nilai ini lebih besar dari 0,05 yang menunjukkan bahwa data variabel motivasi menyelesaikan studi dan kecemasan mendapatkan pekerjaan berhubungan secara linear. Hasil pengujian linearitas dapat dilihat pada tabel berikut:

Tabel 2. Uji Linearitas

\begin{tabular}{cccc}
\hline & & $F$ & Sig \\
\hline Kecemasan & & & \\
Mendapatkan & & & \\
Pekerjaan & Deviation From & 12749, & 0,760 \\
X & Linearity & 171 & \\
Motivasi & & & \\
Menyelesaikan & & & \\
Studi & & \\
\hline
\end{tabular}

Uji hipotesis ini dalam penelitian ini menggunakan analisis statistik parametrik dengan teknik korelasi Pearson Product Moment, hal ini dikarenakan terpenuhinya kedua uji asumsi yaitu data yang diperoleh telah terdistribusi normal dan linear. Jika nilai signifikansi yang diperoleh lebih besar dari $0,05(\mathrm{p} \geq 0,05)$, maka hipotesis ditolak. Sebaliknya jika nilai signifikansi yang diperoleh lebih kecil dari 0,05 ( $\mathrm{p} \leq 0,05)$, maka hipotesis diterima. Hasil pengujian hipotesis dapat dilihat pada tabel.

Hasil analisis data diperoleh angka koefisien korelasi sebesar 0,191 dengan nilai signifikansi 0,144 . Nilai ini lebih besar dari 0,05 yang berarti bahwa tidak ada hubungan yang signifikan antara motivasi menyelesaikan studi dan 
kecemasan mendapatkan pekerjaan. Hasilnya adalah sebagai berikut:

Tabel 3. Uji Hipotesis

\begin{tabular}{cccc}
\hline & \multicolumn{3}{c}{$\begin{array}{c}\text { Kecemasan } \\
\text { Mendapatkan Menyelesaikan } \\
\text { Pekerjaan }\end{array}$} \\
studi \\
\hline Kecemasan & Pearson & & \\
$\begin{array}{c}\text { Mendapatkan } \\
\text { Pekerjaan }\end{array}$ & $\begin{array}{c}\text { Correlation } \\
\text { Sig. (2-tailed) }\end{array}$ & 1 & 0,191 \\
X & N & 60 & 0,144 \\
Motivasi & Pearson & & 60 \\
Menyelesaikan & Correlation & 0,191 & 1 \\
Studi & Sig. (2-tailed) & 0,144 & \\
& N & 60 & 60 \\
\hline
\end{tabular}

Berdasarkan hasil analisis pada tabel 4 ditemukan bahwa kecemasan mendapatkan pekerjaan pada mahasiswa paling banyak ditemukan pada tingkatan kecemasan mendapatkan pekerjaan sedang dengan jumlah 45 orang mahasiswa, kemudian diikuti dengan tingkat kecemasan mendapatkan pekerjaan rendah yakni sebanyak 8 orang dan yang paling sedikit ialah pada kategori tinggi sebanyak 7 orang.

Tabel 4. pengkategorisasian kecemasan mendapatkan pekerjaan

\begin{tabular}{cccc}
\hline \multicolumn{1}{c}{ Skor } & $n$ & $\%$ & Kategori \\
\hline $\mathrm{X}<120,53422$ & 8 & $13 \%$ & Rendah \\
$120,53422 \leq \mathrm{X}<163,4578$ & 45 & $75 \%$ & Sedang \\
$163,4578 \leq \mathrm{X}$ & 7 & $12 \%$ & Tinggi \\
\hline
\end{tabular}

Berdasarkan hasil analisis pengkategorisasian pada tabel 5 ditemukan bahwa motivasi menyelesaikan studi pada mahasiswa paling banyak ditemukan pada tingkatan motivasi menyelesaikan studi sedang dengan jumlah 43 orang mahasiswa, kemudian diikuti dengan tingkat motivasi menyelesaikan studi tinggi yakni sebanyak 9 orang dan yang paling sedikit ialah pada kategori rendah sebanyak 8 orang.

Tabel 5. Pengkategorisasian motivasi menyelesaikan studi

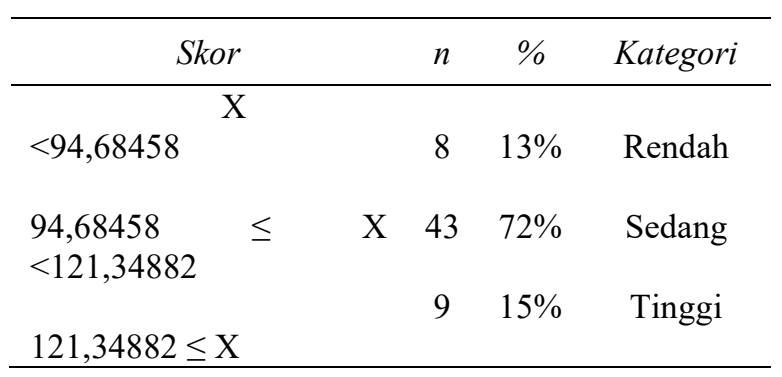

Berdasarkan tabel 6 menjelaskan motivasi menyelesaikan studi dan kecemasan mendapatkan pekerjaan. Hasil menunjukkan bahwa tidak ada mahasiswa yang memiliki kecemasan mendapatkan pekerjaan yang tinggi dan juga tidak terdapat motivasi menyelesaikan studi yang rendah dan 1 mahasiswa yang memiliki kecemasan mendapatkan pekerjaan yang rendah, dan juga memiliki motivasi menyelesaikan studi yang tinggi. Kecemasan merupakan perasaan campuran yang berisikan tentang ketakutan atau kekhawatiran mengenai masa-masa mendatang tanpa sebab khusus untuk kekhawatiran tersebut.

Data lain ditemukan terdapat 3 mahasiswa yang memiliki kecemasan mendapatkan pekerjaan tinggi dan juga memiliki motivasi menyelesaikan studi yang tinggi. Kemudian sebanyak 32 mahasiswa yang memiliki kecemasan mendapatkan pekerjaan yang sedang dan juga motivasi menyelesaikan studi sedang pula, dan tidak terdapat kecemasan mendapatkan pekerjaan yang rendah dan juga tidak terdapat pula motivasi menyelesaikan studi yang tinggi. 
Tabel 6. Hubungan motivasi menyelesaikan studi dengan kecemasan mendapatkan pekerjaan berdasarkan kategori

\begin{tabular}{ccccc}
\hline Kecemasan & \multicolumn{3}{c}{$\begin{array}{c}\text { Motivasi } \\
\text { Menyelesaikan } \\
\text { Mendapatkan } \\
\text { Pekerjaan }\end{array}$} & \multicolumn{3}{c}{ Totali } \\
\cline { 2 - 4 } T & $T$ & $S$ & $R$ & \\
S & 3 & 4 & 0 & 7 \\
R & 5 & 32 & 8 & 45 \\
Total & 1 & 7 & 0 & 8 \\
& 9 & 43 & 8 & 60 \\
\hline
\end{tabular}

Keterangan: R (Rendah), S (Sedang), dan $\mathrm{T}$ (Tinggi).

Penelitian ini bertujuan untuk mengetahui apakah ada hubungan antara motivasi menyelesaikan studi dengan kecemasan mendapatkan perkerjaan pada mahasiswa tingkat akhir Jurusan Antropologi Universitas Halu Oleo. Berdasarkan hasil penelitian ditemukan bahwa tidak ada hubungan antara kedua variabel tersebut pada mahasiswa jurusan Antropologi Universitas Halu Oleo Kendari.

Hasil penelitian di atas relevan dengan penelitian yang dikemukakan oleh Yanti, Erlamsyah, \& Zikra (2013) hasilnya menunjukkan bahwa tidak terdapat hubungan yang signifikan antara kecemasan dalam belajar dengan motivasi belajar siswa. Elliott (1996) menyatakan bahwa pada dasarnya kecemasan ada dalam tingkat yang rendah dan sedang berpengaruh positif terhadap motivasi menyelesaikan studi, salah satunya dapat meningkatkan motivasi menyelesaikan studi, sedangkan kecemasan yang dialami pada taraf tingggi dapat mengganggu dan memperburuk motivasi mahasiswa.

Hasil penelitian ini berbeda dengan penelitian terdahulu yang dilakukan oleh Gadafi, Haiya, dan Ardian (2018), yang melakukan penelitian serupa, hasil menunjukkan bahwa hubungan motivasi mahasiswa tingkat akhir dengan kecemasan menghadapi tugas akhir ada hubungan yang signifikan antara kedua variabel tersebut. Perbedaan akan hasil penelitian ini menunjukkan keberagaman akan hasil data penelitian yang berbeda responden pada setiap daerah.

Penelitian lain juga yang memiliki hasil berbeda adalah penelitian Firmansyah, Azwar, dan Budiman (2018) hasil penelitian menunjukkan bahwa siswa memiliki berbagai macam reaksi saat berada di situasi akademik yang mereka hadapi, reaksi tersebut ada yang berupa reaksi negatif yang bersifat merugikan maupun reaksi positif yang menguntungkan bagi mereka. Hasil menunjukkan bahwa motivasi belajar memiliki hubungan signifikan dengan kecemasan siswa MAN 2 Palembang. Perbedaan akan hasil penelitian ini menunjukkan keberagaman akan hasil data penelitian yang berbeda responden pada setiap daerah, sehingga hasil penelitiannya berbeda berbeda pula hasilnya.

Penyebab tidak ada hubungan dan tidak signifikan antara variabel motivasi menyelesaikan studi dan kecemasan mendapatkan pekerjaan karena ada faktor lain yang mempengaruhinya. Menurut Nevid, Rathus, \& Greene (2005), faktor yang mempengaruhi kecemasan dalam mendapatkan pekerjaan ialah faktor kognitif dan emosional yakni selfdefeating (irasional). Menurut mereka self defeating (irasional) yaitu kecemasan terhadap terbatasnya peluang untuk mendapatkan pekerjaan sesuai dengan jurusannya. Namun berdasarkan hasil penelitian yang telah dilakukan menunjukkan mahasiswa Jurusan Antropologi tidak memiliki kecemasan terhadap ketakutan untuk mendapatkan perkerjaan dikarenakan bahwa saat ini sudah terbuka banyak peluang pekerjaan, lulusan jurusan antropologi saat ini sudah banyak mendapatkan penawaran jenjang karier yang lebih bervariasi, dalam hal ini mahasiswa Jurusan Antropologi memiliki keyakinan dalam mendapatkan pekerjaan walaupun tidak sesuai dengan bidang yang mereka pelajari pada saat di bangku perkuliahan.

Terkait hasil penelitian yang menunjukkan motivasi menyelesaikan 
studi dan kecemasan mendapatkan pekerjaan pada mahasiswa tingkat akhir dalam kategori sedang, hal tersebut dapat terjadi karena saat ini terdapat banyak lowongan pekerjaan yang diperuntukkan bagi lulusan semua jurusan seperti pegawai bank, sales produk, customer service, admin sosial media, operator call center, hingga management trainee (Wicaksono, 2017) yang tidak terlalu memperhatikan latar belakang pendidikan pekerja. Selain itu, dalam penelitiannya menunjukkan bahwa semakin bertambahnya usia individu maka ada kecenderungan kecemasan yang dirasakan semakin menurun. Hal tersebut dapat dikarenakan adanya proses adaptasi individu yang dilakukan secara terus menerus sehingga individu mampu seimbang dalam menghadapi lingkungan yang menekan (Lutfa \& Maliya, 2008).

$$
\text { Dikutip dari strategi }
$$

manajemen.net, Mardiana (2017) melakukan survey mengenai pekerjaan para sarjana yang sesuai dengan jurusannya, ditemukan bahwa sebanyak $63 \%$ sarjana di Indonesia bekerja tidak sesuai dengan bidang keilmuan yang mereka tekuni pada saat di bangku perkuliahan, sehingga membuat mahasiswa menjadi tidak cemas dalam memikirkan peluang kerja mereka kedepannya, hal ini memperkuat hasil penelitian akan munculnya rasa tidak cemas mahasiswa Jurusan Antropologi dalam mendapatkan pekerjaan sesuai dengan bidang ilmunya.

Analisis deskriptif juga dilakukan dalam penelitian ini untuk menentukan pengkategorisasian antara dua variabel yang diteliti, hasilya ditemukan bahwa mahasiswa Jurusan Antropologi di Universitas Halu Oleo tingkat kecemasan mendapatkan pekerjaan berada pada kategori sedang, sehingga kecemasan mendapatkan pekerjaan pada mahasiswa tersebut berada dalam kondisi normal. Menurut Albin (1986) kecemasan yang ada dapat memberi pengaruh positif bila individu menjadi bergairah. Dan sebaliknya kecemasan pula dapat memberikan pengaruh negatif apabila kecemasan sudah berlebihan sehingga menyebabkan individu putus asa. Jadi kecemasan tidak menjadi masalah jika individu tersebut mampu mengelola rasa cemas sehingga tidak mengganggu keseimbangan dirinya apabila ia mencari pekerjaan, sehingga strategi menyelesaikan studi meningkatkan motivasi mahasiswa dalam menyelesaikan studi (Lin, Chen, \& Nien, 2014).

\section{Kesimpulan}

Berdasarkan data penelitian maka disimpulkan bahwa hipotesis dalam penelitian ini tidak diterima. Dari hasil analisis data yang ditemukan bahwa tidak ada hubungan antara motivasi menyelesaikan studi dengan kecemasan mendapatkan pekerjaan pada mahasiswa Jurusan Antropologi Universitas Halu Oleo.

Analisis deskriptif juga menjelaskan bahwa motivasi menyelesaikan studi dan kecemasan mendapatkan pekerjaan pada Jurusan Antropologi paling banyak dialami pada kategori yang sedang.

Kemudian bagi mahasiswa mampu berpandangan positif dengan tetap percaya diri terhadap kemampuan dan potensi yang dimilikinya agar tetap dapat bersaing di dunia kerja dengan menambah pengetahuan dan mencari informasi untuk menyiapkan diri dalam tuntutan-tuntutan dunia kerja nantinya.

Diharapkan kepada peneliti selanjutnya untuk melakukan penelitian lebih lanjut dengan menambah faktor-faktor lainnya yang mempengaruhi permasalahan penelitian seperti self defeating, self efficacy, sosial lingkungan dan sebagainya. 


\section{Daftar Pustaka}

Albin, R. S. (1986). Emosi: Bagaimana mengenal, menerima dan mengarahkannya. Yogyakarta: Penerbit Kanisius.

Agusta, Y. (2015). Hubungan antara orientasi masa depan dan daya juang terhadap kesiapan kerja pada mahasiswa tingkat akhir Fakultas ilmu sosial dan ilmu politik di Universitas Mulawarman. Jurnal Psikologi, 3(1), 369-381.

Azhari, T. R., \& Mirza. (2016). Hubungan regulasi diri dengan kecemasan menghadapi dunia kerja pada mahasiswa tingkat akhir Universitas Syiah Kualah. MEDIAPSI, 2(2), 2329.

Das, S.K,. Halder, U.K,. \& Mishra, B. (2014). A study on academic anxiety and academic achievement on secondary level School Students. Indian Streams Research Journal, 4, 2230-7850.

Durand, V. M. \& Barlow, D.H. (2006). Intisari psikologi abnormal edisi keempat (alih bahasa). Yogyakarta: Pustaka Pelajar.

Elliott. (1996). Educational Psychology. Madition: Brown \& Benchmark.

Firmansyah., Azwar, A. J., \& Budiman. (2018). Motivasi belajar dengan kecemasan siswa dalam menghadapi ujian pada siswa kelas X, XI Di MAN 2 Palembang. Skripsi. Tidak diterbitkan. Fakultas Psikologi Universitas Islam Negeri Raden Fatah Palembang.

Gadafi, I., Haiya, N. N., \& Ardian, I. (2018). Hubungan motivasi mahasiswa tingkat akhir dengan kecemasan menghadapi tugas akhir Di Fakultas Ilmu Keperawatan (FIK) UNISSULA. Skripsi. Tidak diterbitkan. Universitas Islam Sultan Agung. Semarang.

Hanim, L. M., \& Ahlas, S. (2020). Orientasi masa depan dan kecemasan menghadapi dunia kerja pada mahasiswa. Jurnal Penelitian Psikologi. 11(1), 2087-3441.

Hooda, M \& Saini, A. (2017). Academic Anxiety: An Overview. Educational Quets an int. J. of Education and Applied Social Science. 8(3), 807810.

Lestari, N. A. (2012). Hubungan ekspektasi terhadap dosen pembimbing dengan motivasi menulis skripsi. Educational Psychology Journal, 1(1), 1-8.

Lin, H., Chen, W., \& Nien, S. (2014). The study of achievement and motivation by e-learning-a case study. International Journal of Information and Education Technology. 4(5), 421-425.

DOI:10.7763/IJIET.2014.V4.442

Lutfa, U., \& Maliya, A. (2008). Faktorfaktor yang Mempengaruhi Kecemasan Pasien dalam Tindakan Kemoterapi di Rumah Sakit Dr. Moewardi Surakarta. Jurnal Biomedik (eBM), 1, 642-645.

Mardiana, C. F. (2017, Agustus). Strategi Manajemen.net: Diakses melalui link:Https://finance.detik.com/beritaekonomi-bisnis/d-3620313/63orang-indonesia-bekerja-tak-sesuaijurusan. 
McClelland, D. C. (1987). Human Motivation. New York. Cambridge University Press.

Nadziri, M. (2018). Kecemasan menghadapi dunia kerja pada mahasiswa akhir dengan jurusan yang diprediksi sulit mendapat pekerjaan. Skripsi. Tidak diterbitkan. Fakultas Psikologi Universitas Muhammadiyah Malang. Malang.

Natalya, L. \& Purwanto, C. V. (2018). Exploratory and confirmatory factor analysis of the Academic Motivation Scale (AMS)-Bahasa Indonesia. Jurnal Makara Hubs-Asia. 22(1), 29-42.

Nevid, J. S., Rathus, S. A. \& Greene, B. 2005. Psikologi Abnormal. Edisi Kelima. Jilid 1. Jakarta : Erlangga.

Nugroho, F. W., \& Karyono. (2015). Hubungan antara hardiness dengan kecemasan menghadapi dunia kerja pada mahasiswa tingkat akhir. Jurnal Empati, 3(3), 76-84.

Ramaiah, S. (2003). Kecemasan Bagaimana Mengatasi Penyebabnya. Jakarta: Pustaka obor

Rosliani, N., \& Ariati, J. (2016). Hubungan antara regulasi diri dengan kecemasan menghadapi dunia kerja pada pengurus ikatan lembaga mahasiswa Psikologi Indonesia (ILMPI). Junal Empati. 5(4), 744-749.
Susantoputri., Kristiana, M., \& Gunawan, W. (2014). Hubungan anatara efikasi diri karier dengan kematangan remaja di daerah Kota Tangeran. Jurnal Psikologi Universitas Kristen Krida Wacana, 10(1), 67-73.

Wicaksono, D. R. (2016). Hubungan antara Dukungan sosial dengan kecemasan dalam menghadapi dunia kerja pada mahasiswa. Jurnal Humanitas, 2(5), 67-75.

Yanti, S., Erlamsyah., \& Zikra. (2013). Hubungan antara kecemasan dalam belajar dengan motivasi belajar siswa. Jurnal Ilmiah Konseling. 2,(1), 1-6.

Yuniarto, A. (2017). Hubungan rencana karir dengan motivasi menyelesaikan studi pada mahasiswa $\mathrm{S} 1$ bimbingan konseling. Indonesia Journal of Guidance and Counseling, 6(2), 2252-6374.

(2012, Oktober). 10 Jurusan kuliah yang paling sulit dapat pekerjaan Finance.detik.com. Berita Ekonomi Bisnis. Diunduh dari: https://m.detik.com/finance/beritaekonomi-bisnis/d-2062348/10jurusan kuliah-yang-paling-sulitdapat-pekerjaan-1. 